\title{
Private Narratives and Infant Views: Iconizing 1970s Militancy in Contemporary Argentine Cinema
}

Shot in 2011 and released in September 2012, Infancia clandestina, by Argentine director Benjamín Ávila, has already been sold to over twenty countries, has been granted five prestigious international prizes and ten of the most important local prizes, has been nominated for at least twelve more, and selected to compete under the category 'Best Foreign Film' for the 2013 Oscar Awards (Scholz, 2012). These achievements, though impressive, are far from surprising. An international coproduction featuring famous actors, the movie condenses all the necessary characteristics in order to successfully appeal to a global audience: it is a moving story of the dictatorship narrated from a child's perspective and directed by the son of a disappeared activist. In fact, the film was from the outset conceived and marketed as a sequel to Academyaward winners La historia oficial and El secreto de sus ojos, two successful examples of how the so-called 'Dirty War' has become the country's alluring trademark within the global world. ${ }^{1}$

Yet, even when many readings acknowledge these popular features, most of them highlight the film's originality. Although Infancia clandestina is a story about a topic as recurrent as the dictatorship, its main merit lies precisely in its unique approach to such a controversial epoch. As opposed to traditional cultural production, which focuses on the horrors

\footnotetext{
${ }^{1}$ We could in fact say that the term 'Dirty War' itself has become an international trademark in spite of its ideological connotations. It was coined by the military junta in order to justify their clandestine actions: a 'dirty enemy' allowed for 'dirty methods' and for a 'dirty war'. The use of the term is hence problematic: it indirectly repeats the military's justifications and it helps to consolidate the idea that the dictatorship was a war, thus assigning an equal status to government officials and to civil militants while wiping away the responsibilities of Argentine society. For an in-depth explanation of the use and misuse of the notion of war in the Argentine case, see Vezzetti, 2002: 55-108. Perhaps the best indicator that the term has become an international trademark is the fact that people in Argentina prefer 'military dictatorship' and that most of them probably do not even know what 'Dirty War' refers to.
} 
of state violence, this movie openly talks about left-leaning violence. Breaking with the common representation of the disappeared as the passive victims of repression and torture, the film depicts them as active guerrilla fighters with their guns, their militant rituals, their political affiliations, and their straightforward commitment to the armed struggle. Appealing to a fictional lens, Ávila revisits a well-known historical period but provides an innovative angle: a highly-politicized portrayal of revolutionaries, in particular of radical Montoneros. ${ }^{2}$ Two interrelated cinematic strategies make this innovation possible: the use of a child's perspective and the inclusion of anime-style cartoons. The infant gaze allows for a first-hand account of activism. As the young protagonist witnesses his militant parents' daily life, he is able to provide an inside narration of the details surrounding their political organization. The cartoons help to avoid the representation of state violence that dominates traditional cultural production. Deaths, shootings, and kidnaps are obliquely exposed, mitigated by the animated techniques of the medium. In sum, most critics agree that these two strategies are at the heart of the film's main achievements: eluding a naturalized view of the 1970s and designing a novel construction based on an original representation of militancy (Ranzani, 2012; Pérez Zabala, 2012; Feinmann, 2012; Kairuz, 2012)..$^{3}$

\footnotetext{
${ }^{2}$ The Movimiento Peronista Montonero was formed around 1970 as an urban guerrilla movement mostly composed of left-leaning Peronists and Roman Catholics. It was completely dismantled by 1979 . This early defeat is often quoted as a proof that the military's justification for a dictatorship that lasted until 1983 was (at least partially) false. For further information on Montoneros, see Donatello, 2010; Gelman, 1987; Gillespie, 1998; Giussiani, 2011; Moyano, 1995; Vezzeti, 2002 and 2009.

${ }^{3}$ There are also some readings that do not focus on the representation of militancy and that instead interpret the film as another example of a post-dictatorial narrative that comes to grips with a traumatic experience by engaging in memory work (Feierstein, 2012: 124-144 ; Aon, 2011: 219-230; Young, 2012). I take these readings as an indication of the problems entailed by the recurrent application of the psychoanalytic framework, which - in the Argentine case - ends up yielding the same interpretation for every narrative, regardless of its specificity and conditions of production. See Garibotto, 2010 for a more detailed examination of this problem.
} 
In this article I argue that what happens in the film — and what, in the end, makes it such a valuable cultural product - is in fact the opposite. Instead of providing a unique portrayal of the 1970s based on an innovative exposition of left-leaning violence, this coming-of-age story fits within a version of militancy that has become quite common since the mid-1990s. Instead of presenting undisclosed aspects of the armed struggle, the movie relies on a privatized and archaic image of the disappeared activist, which ultimately transforms 1970s militancy in an iconic sign. The above-mentioned readings are only accurate if we accept two important omissions: if we consider that the figure of the disappeared as a passive victim is the most common symbol (thus overlooking the existing predominant representation of the disappeared as a heroic militant) and if we disregard both contemporary Argentine official discourse and second-generation cultural production. Breaking with the leading interpretation that praises Ávila's film because of its originality, I contend that its most interesting feature lies in its commonality. Infancia clandestina 's repetitions help us to perceive a second pattern in the representation of activism that originates in the mid-1990s and solidifies after 2003 with the advent of the Kirchner administration. This second pattern is at the core of the contemporary iconization of $1970 \mathrm{~s}$ militancy; an iconization that, as the international success of the movie suggests, is also occurring at the global level. Far from being a brand new creation, Ávila's film is a good example of how contemporary Argentine cinema both registers and participates in this iconizing process. An analysis of the use of a child's perspective and of anime-like cartoons illuminates this participation and elucidates the connections between these filmic strategies, the privatization of left-leaning violence, iconicity, and (the preclusion of) historical examination.

\section{Private Narratives: The Subjective Turn in the Representation of Left-Leaning Violence}


At first sight, everything in Infancia clandestina is politically marked. Juan's childhood is entirely crisscrossed by revolutionary militancy. He lives under the name Ernesto in a secret house; his parents and his uncle Beto belong to Montoneros and hold underground meetings with their fellow guerrillas in front of his eyes; and he has immediate access to firearms, bullets, hideaways, and dissident rituals. For Juan, political activism is not covert information that he needs to figure out: his mother allows him to witness everyday militancy and in fact uses Che Guevara's life as a point of reference to explain how he should act. Although Juan might still be considered a child, he is not spared violent details, no matter how painful. His father, for example, gives him an in-depth account of uncle Beto's death, including how, upon being caught by a military officer, he decided to swallow a grenade, hug his captor, and put an end to both lives.

It is because of this open account of the left-leaning armed struggle that, as I mentioned earlier, most readings emphasize the film's originality. As opposed to the naturalized representation of the 1970s as a period dominated by state violence, Juan's coming-of-age story helps to expose undisclosed aspects of this particular historical moment. In fact, the search for an innovative angle is, according to Ávila, the movie's point of departure: 'Me parece que las historias que se habían contado en relación a la dictadura olvidaron dar cuenta de esos militantes que estaban dispuestos a dar sus vidas por sus ideales [...] Yo asumí el desafío y el riesgo de contar la Historia desde ese costado' (Ávila, 2012). Breaking with traditional post-dictatorial cultural production, Infancia clandestina aims to denaturalize the most common constructions of the recent past, to explore its hidden facets, and to bring the forgotten image of disappeared activists to the fore. 
Yet this widespread assertion of originality conflicts with the film's actual references to Argentine history, especially (and surprisingly) when alluding to the causes leading to the armed struggle and to the motivations for left-leaning violence. The mother's generalizations when she voices the founding principles behind her organization are a good example of this lack of innovation. According to her, Montoneros are fighting for a revolution because they are looking for justice and because they want to raise popular consciousness. Curiously enough, this is the only explanation for engaging in political activism that the movie provides. A similar vagueness can be seen in the closing captions: 'Dedicado a la memoria de mi madre, Sara E Zermoglio, detenida-desaparecida el 13 de octubre de 1979. A mis hermanos, mi padre, mis hijos. Y a todos los Hijos, Nietos, Militantes y a todos aquellos que han conservado la fe'. Throughout the film, as condensed in these final words, militancy is conceived as an everyday, domestic, and even family activity; as a personal virtue and an abstract heroic faith; as a subjective and affective history. Not only are these features perceived in the closing dedication, a formula generally prone to private emotions. The opening captions, which are meant to provide historical context and to situate the narration within a particular period, are also based on a well-known simplification:

1975: tras la muerte del presidente Perón grupos parapoliciales comenzaron a perseguir y asesinar militantes sociales y revolucionarios. 1976: los militares tomaron el poder por la fuerza, se desencadenó la más violenta represión en la historia de la Argentina. 1979: desde su exilio en Cuba, los dirigentes de la organización revolucionaria montoneros lanzaron la Operación Contraofensiva. Algunos militantes regresaron a la Argentina con sus hijos. ${ }^{4}$

\footnotetext{
${ }^{4}$ As Hugo Vezzetti explains, the idea that left-leaning violence originated as a reaction against state violence has become a topic in post-dictatorial Argentina. This topic, he argues, both precludes further historical examination and erases the ideology of the armed activists themselves (2009: 50).
} 
Far from being an original account of activism, Infancia clandestina embodies the characteristics at the core of what Hugo Vezzetti calls the 'subjective turn' in the representation of militancy (2009: 110); a pattern that began in the mid-1990s and that became dominant after 2003. According to Vezzetti, there are two common images of the disappeared in Argentine culture: the disappeared as a victim of state violence and the disappeared as a militant. The former is a result of the combination of global and local factors. Since Auschwitz, the notion of memory has been grounded almost exclusively in the figures of the victim, the crime perpetrator, and the witness. The global popularity of memory studies, deeply rooted in the concept of trauma, has further enhanced the significance of these images, especially because 'trauma' is usually conceived as an abrupt occurrence that is unexpectedly suffered by a passive subject. In the Argentine case, these notions became particularly relevant in the early democracy. The public staging of the trials against the military and the success of testimonial narratives epitomized by the Nunca más helped to solidify the crime perpetrator/victim/witness triad through the use of legal discourse. The figure of the disappeared as a victim was the only relevant possibility for the juridical process, for which factors such as political affiliation were not pertinent when elucidating criminal responsibility. In this socio-juridical context, allusions to the left-leaning armed struggle, which had been at the center of public discourse between the 1960s and the 1980s, vanished. ${ }^{5}$ Yet in the mid-1990s these allusions resurfaced, allowing for a second pattern: the figure of the disappeared as a militant. Testimonial narratives and films such as Martín Caparrós’s and Eduardo Anguita’s La voluntad and David Blaustein’s Cazadores de utopías began to incorporate the figure of the disappeared as an activist often committed to the armed

\footnotetext{
${ }^{5}$ See Franco, 2012 and Vezzetti, 2009: 61-129 for an account of the public discussion regarding revolutionary violence between the late 1960s and 1983.
} 
struggle. Scholarly texts, like Pilar Calveiro’s Política y/o violencia and Claudia Gilman’s Entre la pluma y el fusil, openly addressed revolutionary violence. This second pattern has become prominent since 2003 , fueled by the centrality of the organization H.I.J.O.S., which explicitly acknowledges missing activists' political ideals, and by the official discourse of the Kirchner administration, which frequently relies on the image of the 1970s heroic militant. ${ }^{6}$ Attuned to this increasing visibility, contemporary theater, literature, and cinema (in particular secondgeneration documentary production) make the figure of the militant the center of their explorations. $^{7}$ Although there are some variations, especially between academic works and cultural products, Vezzetti points to a series of motifs at the core of this second construction: abnegation, courage, heroism, sacrifice, and youth. Despite the public and collective edge of the notion of militancy, this second representation is based on private virtues, attesting to the abovementioned subjective turn. Rather than a collective action, militancy is transformed into a private lifestyle, into an everyday individual routine. This second representation hence erases the political dimension of activism, and at the same time privatizes and romanticizes revolutionary violence. Che Guevara's image becomes the emblem of this second representation: '[del] Che Guevara solo se toman las cualidades personales [...] Es la leyenda del "guerrillero esencial" en

\footnotetext{
${ }^{6}$ The organization H.I.J.O.S, whose members are children of disappeared people, was formed in 1995 and became especially visible after 2003 due to the support of the Kirchner administration. The founding principles explicitly acknowledge the missing parents' political ideals: 'Reivindicamos el espíritu de lucha de nuestros padres: porque ellos querían cambiar la sociedad, querían que las cosas fueran diferentes y por eso se los llevaron' (HIJOS, 1995). A clear example of the government's allusions to the figure of the 1970s heroic militant can be found in Néstor Kirchner's famous speech at the Escuela Superior de Mecánica de la Armada for the 28th anniversary of the military coup: 'cuando recién veía las manos, cuando cantaban el himno, veía los brazos de mis compañeros, de la generación que creyó y que sigue creyendo en los que quedamos que este país se puede cambiar [...] Queremos [...] tomar como ejemplo a aquellos que son capaces de dar todo por los valores que tienen y [hubo] una generación en la Argentina que fue capaz de hacer eso, que ha dejado un ejemplo, que ha dejado un sendero, su vida, sus madres, que ha dejado sus abuelas y que ha dejado sus hijos. Hoy están presentes en las manos de ustedes' (Kirchner, 2004).

${ }^{7}$ For some recent paradigmatic examples in the three fields, see: Roqué, 2004; Carri, 2003; Prividera, 2007;

Bruschtein, 2009; Arias, 2009; Pérez, 2012; Gamerro, 2011; Zuker, 2003.
} 
la que el ejemplo personal y la moral del sacrificio absoluto arrasan con la razón política' (Vezzetti, 2009:139). ${ }^{8}$

The subjective turn in the representation of militancy is at the core of Infancia clandestina. Mediated by Juan's lens, activism becomes an everyday routine, as normal and familiar as any household chore. Bullets and firearms, rather than being perceived as historical markers, are converted into domestic picturesque ornaments. Che Guevara, instead of being a political figure, embodies the fairy-tale features of a child's hero: he is an epic character that travels around the world and skillfully outwits his enemies by changing his clothing. The same romantic attributes are attached to all the militants that Juan encounters. From his perspective, his parents, his uncle, and their friends are brave and young soldiers, passionately fighting for their ideals. Every dialogue that he witnesses-especially the one in which his father tells him about Beto's death and the one in which his mother explains the values of fighting - unveils the private virtues mentioned by Vezzetti: abnegation, courage, heroism, sacrifice, and youth. In line with Argentine discourse since the mid-1990s, political militancy sheers away from collective action, becoming an individual trait. As Hancevich and Soler argue, since the mid-1990s 'la reconstrucción y el retrato de los desaparecidos tienen por escenario privilegiado la vida cotidiana [...] Se trata, entonces, de un "desaparecido normalizado" [cuya vida está] impregnada por un fuerte romanticismo' (Crenzel, 2010: 102). Ávila himself alludes to this subjective turn in an interview with Mariano Kairuz: 'Y yo quería justamente eso: dar una visión más humana de

\footnotetext{
${ }^{8}$ The articles compiled by Emilio Crenzel in Los desaparecidos en la Argentina mostly coincide with Vezzetti's observations, both in terms of chronology and of the subjective and privatized components of this second pattern. The texts also trace an itinerary that begins with the figure of the disappeared as an 'innocent victim' $(2010: 21)$ in the early democracy and ends with the figure of the disappeared as a 'normalized militant' (2010:102) that originates in the mid-1990s and consolidates after 2003.
} 
cómo fueron las cosas, como yo las recordaba, no esa construcción de mucho miedo, pánico y horror que se hizo luego. Hubo miedo y horror, por supuesto, pero también mucho humor, amor, risa, diversión; mucho cotidiano’' (Kairuz, 2012).

\section{Infant Views: the Intensification of Affect and Iconicity}

As I mentioned earlier, most readings tie the film's originality to the use of a child's perspective. But what exactly is a child's perspective and in what way does Infancia clandestina organize its cinematic strategies around this notion? At first sight, the answer seems quite obvious: the movie's main protagonist is a child and the plot is based on his coming-of-age story. The audience accompanies him as he returns from exile, interacts with his parents, goes to school, falls in love, gets upset about his uncle's death, and celebrates a fake birthday. The answer seems less obvious, however, if we take into account that the opening shot captures a sleeping Juan, i.e. a child with no perspective. Actually, the first scene is told through the mother's viewpoint. The camera follows her gaze as she casts her eyes on her sleeping son, stares at the rain drops on the car window, and looks at the deserted streets. In spite of the child being present in every scene and of the cinematic sequence carefully developing his story, some images - like the opening shot portraying the car nap — are not based on his perspective. In fact, in the movie there are only two types of images that are strictly built around an infant point of view: a series of shots in which the camera mimics Juan's gaze and the anime-style cartoons. Although this distinction might seem like a technicality, it is of the utmost importance when analyzing the film's ideological undertones; especially because these scenes are precisely the ones that, instead of eluding a naturalized representation of the 1970s, transform them in an iconic sign. 
Film scholars in the Peircean tradition have already emphasized that cinematic images are iconic signs. ${ }^{9}$ Stephen Prince even argues that iconicity is the medium's most salient feature, for it endows images with mimetic and affective qualities. Since cinematic images are visually isomorphic with real-world images, they are more eagerly apprehended than, for example, the written language that forms a novel:

Via the technologies of motion picture recording, the camera is able to reproduce in clearly recognizable and even intensified form the familiar streams of facial and body motion cues [...] These cues should be readily understood by cinema viewers, just as they are in realworld visual experience. If the distinctions between iconic and symbolic modes that we have been emphasizing are really relevant to differences between pictures and language, then one would expect iconic modes to be processed more readily than symbolic ones (1999: 114).

Because filmic images look like the real world, they resonate in a way that other types of images do not: they appeal to the viewer both cognitively and affectively. The mimetic qualities of visual resemblance connect to the viewer's psyche and subjectivity, eliciting an affective response. ${ }^{10}$ Yet if all cinematic images, due to their iconic status, carry an affective component, some of them enhance it. In particular, as Prince suggests, close-ups, which 'intensify and

\footnotetext{
${ }^{9}$ Peter Wollen, Philip Rosen, Kaja Silverman, Stephen Prince, and Mary Ann Doane, among others, explain that film is a sign system which encompasses indexical, iconic, and symbolic signs. Cinematic images are primarily indexical signs because a real referent is required for their configuration. As it happens with the finger and the fingerprint, there is an existential bond between sign and referent: the profilmic objects have to be in front of the camera while being shot so that an image can be formed. At the same time, filmic images are iconic signs because they visually resemble the referent: the close-up of Juan's face both requires the presence of the actor's face in front of the camera and looks like that face. Finally, filmic images also include symbolic signs, i.e. signs that do not establish an existential or a visual connection to the referent but a conventional one. Verbal language, plot, narrative structure, and genre codes are good examples of symbolic signs.

${ }^{10}$ In this article I am following Laura Podalsky's distinction between 'affect', 'emotion', 'feeling', and 'cognition'. For her, affect is a sensorial feeling that could be considered as a presocial embodied intensity, because its meaning has not been socially codified. On the contrary, emotion is a sensorial feeling that is 'socially inscribed into an already constituted signifying network' (2011:12). Following recent theorizations that show the interrelatedness of body and mind, she states that feeling, affect, and emotion are integral to cognition and partners to reason (2011: 810). Although Podalsky convincingly argues that in film the existence of affect goes beyond the notions of iconicity, mimesis, and the gaze, my analysis of Infancia clandestina focuses on these notions because I find that these three dimensions are still the most prominent manifestations in this particular film. Also, as Podalsky explains, although the appeal to sensations is not necessarily depoliticizing, in this movie (as I will argue in the following paragraphs), the historical situatedness of feelings and the intensification of existing emotions precludes political examination.
} 
emphasize the most salient cues for the viewer's understanding in cognitive and affective terms' (1999: 113).Close-ups allow the viewer to delve into the screen, to explore in depth objects that resemble the ones that he or she finds in the real world. Close-ups magnify the world that was in front of the camera and that the audience recognizes as their own real world. The close-up enhances iconicity and intensifies affect. Or, as Béla Balász, one of the first thinkers to theorize this representational technique, observes: 'Good close-ups radiate a tender human attitude [...] a delicate solicitude, a gentle bending over the intimacies of life-in-the-miniature, a warm sensibility. Good close-ups are lyrical; it is the heart, not the eye, that has perceived them' (1999: $305)$.

If we analyze the scenes that are strictly built upon a child's perspective, we could say that in Infancia clandestina the infant point of view enhances iconicity and intensifies affect. This is especially evident in the images in which the camera mimics Juan's gaze, which always compose the same sequence. First, there is a close-up of the child's face that connects the viewer to his eyes; then, there is a scene that seems to be perceived through these eyes; and, finally, there is a character that looks at Juan and whose external gaze (captured by a long shot) puts an end to the boy's view. In this sequence the close-up is the most predominant cinematic technique: it ties the viewer's gaze to the child's eyes and magnifies the objects that are supposedly perceived through these eyes. Via the infant gaze, things and persons are enlarged. The mimetic qualities of the filmic images are enhanced; affective and emotional responses are intensified. In other words, the infant gaze adds an additional layer of iconicity. Interestingly enough, this sequence systematically occurs in two instances: whenever Juan witnesses actions pertaining to militancy (a firearm exchange, an underground meeting, his mother singing a political hymn, an oneiric apparition of his dead uncle) and whenever he contemplates María, the 
girl he loves. In Ávila's movie militancy and affect cannot be disentangled, as they are connected both formally (via the close-up) and thematically (via sentimental love). The recurrent parallel between Juan's mother (the main activist protagonist) and María highlights this connection. Juan’s daydreams about María immediately precede a bucolic picnic with his mother. The boy's romantic contemplation of María's dance performance parallels the sentimental observation of his mother singing a political hymn. In fact, the two actresses look notoriously alike, as does Benjamín Ávila's real mother whose photograph appears in the film’s final credits.

Affect and iconicity are further intensified via the use of temporality. These sequences meticulously combine the close-up with slow-motion shots, creating the impression that the child's gaze interrupts the normal flow and puts persons and objects outside of conventional time. Past, present, and future are indistinguishable and collapse into one. Causality is superseded by duration. Juan's view seems to make things eternal, ahistorical, untouched by the passing of time. Through his gaze the movement-image gives way to the time-image: i.e. 'the linkages of situation-action, action-reaction, and excitation-response' (Deleuze, 1986: 211) give way to the privileging of 'purely optical situations' over action (Deleuze, 1999: 3). The logic of observation replaces the logic of cause and effect, of action and reaction, of progress. These slow-motion scenes do not advance the plot but seem to interrupt its development. Or, to borrow Walter Benjamin's terms, the infant gaze seems to restore the scene's aura: 'its presence in time and space, its unique existence at the place where it happens to be' (1999: 733). Via Juan's eyes, militancy becomes auratic and is thus filled with cult value. Bullets and weapons are not just the accompanying scenery: they occupy the entire frame, as if they were eternal works of art. The uncle and his fellow activists are more than additional characters: they conquer space and interrupt time, as if they were epic heroes. Juan's mother and girlfriend are much more than 
everyday persons in the child's life: they are so close and move so slowly that, paradoxically, become unreachable. Close-up and slow motion transform them into two distant idols that Juan adores, reminding us of Benjamin's claim: 'The definition of aura as a "unique phenomenon of a distance however close it may be" represents nothing but the formulation of the cult value of the work of art in categories of space and time perception' (1999: 736). The firearm exchange, the underground meetings, and the political hymns are not routine practices but auratic rituals that are close yet unreachable, devoid of history, and embedded in cult value.

In The Politics of Affect and Emotion, Laura Podalsky observes that many scholars (such as Nelly Richard, Beatriz Sarlo, and Jean Franco) criticize post-1990s films for being depoliticized and usually quote their appeal to feelings as an index of this depoliticizing edge. Genre films that deal with the 1960s and 1970s are especially criticized for wiping away historical specificity in favor of narrative or character development and for casting the past into the already known. Breaking with this scholarly tradition, Podalsky proposes to rethink the role of emotion and affect and how they can intersect with politics in order to offer a more complex account of the cinematic field. Although the above-mentioned scholars draw a distinction between cognition and feeling and consider that only the former is able to account for a proper representation of history, Podalsky explains that contemporary studies conceive of feeling, affect, and emotion as partners to reason and integral to cognition. As opposed to the cognitivists' approach, which sees cognition as an autonomous level and feelings as universal attributes located within the individual, new studies emphasize the historical situatedness of feelings and highlight that film can shape affect and unsettle given emotions, and not only reflect them. In times of the rationalization of politics and when the legacy of the dictatorship is carried away by truth commissions, certain political thrillers-Podalsky argues—can probe the past in 
new ways. Their appeal to feelings can provide a sense of urgency that allows for radical interrogation by shaping new types of affect, disturbing existing emotions, and creating new sensibilities (2011: 60-80).

Although I find Podalsky's arguments quite compelling, I believe that it is precisely the historical situatedness of feelings that is at the core of Infancia clandestina's naturalized representation of the past. The infant account of activism, rather than creating a sense of urgency for interrogating the 1970 s, repeats and solidifies the predominant emotional discourse on leftleaning militancy. If the film shapes affect, this affect coincides with an already-given emotion toward radical militancy, precluding the emergence of a new type of sensibility. In other words, had this particular representation materialized between the 1980s and the mid-1990s, when revolutionary violence was absent from public discourse, it would have possibly allowed for a novel interrogation of the recent past. But since the film was released in 2012, when the emotional appeal to militancy has become hegemonic and plays a central role in the prevalence of the subjective turn, this particular representation ends up crystallizing the past and preventing the audience from engaging with history. Furthermore, the shaping of a new type of affect is precluded by the interlocking relationship between militancy and sentimental love. Romantic love (an already-given and socially-inscribed emotion) fuels the representation of activism, preventing the formation of a new sensibility. Instead of creating new kinds of affect or unsettling given emotions, the child's perspective mimics an existing feeling toward militancy and even enhances it via close-ups and slow motion. The infant gaze triggers well-known sensations, allows the viewer to identify and solidify an existing representation, and intensifies iconicity. Or, to put it in semiotic terms, the symbolic and the indexical dimensions contribute to the process of iconization, inhibiting new affective configurations. The repetition of historically- 
marked social conventions (i.e., 2012 existing representations of militancy and sentimental love) contribute to the sedimentation and enhancement of the 1970s as an iconic sign. ${ }^{11}$

The role of the indexical and the symbolic dimensions in this process of iconization also becomes apparent if we pay attention to Infancia clandestina's photos and verbal language. A series of photographs of Benjamín Ávila's childhood, especially of his disappeared mother, accompanies the final credits. If, as Marianne Hirsch suggests, the photograph is 'the index par excellence' (2001:14), in this specific case the indexical is somewhat erased. The pictures are so small and distant that the images become indistinguishable. On several occasions the audience wonders if they are seeing the real mother's portrait or a photo of one of the two main actresses. The photographs' referential value is undermined. Since it is almost impossible to link sign and referent, pictures lose their indexical status. They are converted into another iconic image of the 1970s. Something similar happens to verbal language. Throughout the film two different generations dialogue: militants and children. Although at first sight it might look like these dialogues draw an inter-generational connection, they actually create a dissonance that separates them in time. While children use contemporary language ('Te colgaste'; 'Está para darle'), activists use typical 1970s vocabulary ('estaba podrida la cita'; 'Beto cantó'). Even when it is the children's language the one that is anachronistic (pointing to a future time that does not coincide with the movie's main setting), it is the first generation`s language that—by contrast—sounds

\footnotetext{
${ }^{11}$ The constant interaction between symbolic, indexical, and iconic dimensions was noted early by Peirce himself. As he explained, there are always overlapping functions in a single signifying identity. Icons, for example, are present in every type of sign because we always have mental images of the referent. Linguistic statements, which are mostly symbolic signs, depend on indices to be transformed into specific statements (i.e., into historically-marked statements, into statements that are specific to time and space). Finally, all signs depend on convention from the outset or can become conventionalized, relating themselves to the symbolic. This is especially evident in the case of iconic signs: without convention the creation of a mental image would be impossible. Although all signs result from the triadic relationship between these dimensions ('thirdness'), what defines a sign as an icon, index, or symbol is the prevalence of one of the three dimensions over the others. See Silverman, especially pp 20-25 for a detailed explanation of overlapping functions in Peircean semiotics.
} 
archaic. Like the objects captured by Juan's gaze, the militants' vocabulary lies outside of time, untouched by history. Their words are an auratic residue of the past; a relic embedded in cult value. In Infancia clandestina the three semiotic dimensions, as Peirce suggested, overlap. Indexical and symbolic components join the infant gaze to intensify iconicity, transforming 1970s militancy in a highly iconic sign.

The inclusion of anime-style cartoons further heightens this process. These images also appear every time that the movie refers to militancy and in this sense parallel the scenes in which the camera mimics the child's gaze. The anime-style cartoons portray shootings, deaths, and leftleaning violence. They depict the family's exile and summarize Che Guevara's epic journey. The anime pictures serve as a graphic condensation of activism, as a graphic summary of those images that had previously been presented, via close-ups and slow motion, through Juan's eyes. We could in fact say that the cartoons further iconize the already iconic. The pictures add a third layer of iconicity to 1970 s activism: they further iconize a representation that was already doubly iconic both because of its filmic medium and because it had been emotionally enhanced through the child's lens. Or, as Argentine cultural critic Quintín observes, 'los fotogramas se convierten en cuadros de historieta y así quedan congelados como hechos de una historia que no se cuestiona' (2012).

This intensification of iconicity involves significant ideological consequences. As Peirce noted, iconicity is a result of the mixture of repetition and stability (1982:78). An icon is formed because a sign continually resembles a stable referent. To put an everyday example: since a map regularly refers to a stable geographical area, people are able to visually associate the map with the area. Iconic signs require both repetition of a particular image and stability of a steady 
referent. Yet the process is even more complex. For Peirce, the referent does not exist independently of the sign; it only exists within the semiosis. ${ }^{12}$ Because reality remains impervious to thought until we represent it, the referent is only available when it is linked to a particular sign. In other words, the geographical area is a geographical area only because we are codifying it as such. The symbolic thus plays a key role in the constitution of the referent: habit, convention, and law make the referent possible. Thus, in iconic signs there is a tight connection between convention, image, and referent—between the symbolic, the iconic, and the object. An icon emerges as a result of a conventionalized association between an invariable sign and an invariable referent; an association that is repeated and sedimented over time. This association invites a prompt response but precludes further examination: the map instantly evokes the geographical area and requires no further consideration.

If we take into account this relationship between repetition and stability, the ideological consequences of the enhancement of iconicity become apparent. The iconic representation of activism in Infancia clandestina is based upon a repetition that calls for an instantaneous response but prevents further analysis. The (triple) iconic representation repeats existing emotions and solidifies an archaic figure of a privatized, romanticized, and auratic militant. Cinematic images evoke a conventionalized, sedimented, and stable referent that is well known by the audience and that does not ask for further examination. Ávila himself inadvertently supports this interpretation when he mentions in passing that: 'Con Infancia clandestina espero

\footnotetext{
${ }^{12}$ For Peirce, we have direct experience but indirect knowledge of reality. We know that there is a world of things but we have no intellectual access to it unless we represent it. He thus distinguishes between two types of referent ('objects'): the 'immediate object', the object as represented in the sign, and the 'dynamic object', the object as it really is. Given that I am interested in elucidating how 1970s militancy becomes an iconic sign (i.e, how 1970s militancy is being represented), in this article the word 'referent' corresponds to Peirce's immediate object, to the referent within the semiosis.
} 
varias cosas. En lo personal, muchas, pero [...] de mi generación, espero que se sienta identificada con la posibilidad de creer. Y en cuanto a la de mis hijos, espero que Infancia clandestina sea una película que les sirva para poder quitarle peso a la discusión política' (Ranzani, 2012).

\section{0s Militancy in Contemporary Argentina: the Making of a Global Iconic Sign}

In Latinamericanism after 9/11 John Beverley suggests that a 'paradigm of disillusion' (2011:

96) dominates the representation of the armed struggle in contemporary Latin America:

[T] he armed struggle remains largely bracketed away from public memory in Latin America [...] This is so partly because young people in Latin America today, unlike Sarlo's or my generation, have no direct biographical connection to the armed struggle. But that inevitable generation gap is aggravated in turn by the fact that the representation of the armed struggle they do have access to, like Castañeda's Utopia Unarmed, give on the whole a negative image of it. That image is in turn governed by what I am calling here the paradigm of disillusion [which] rests on a coming-of-age narrative [...] Its underlying idea is something like the following: The illusion of the revolutionary transformation of society that was the inspiration of the armed struggle was a kind of romantic adolescence (2011: 99).

According to Beverley, this vision of the armed struggle as an adolescent error is based both on the figure of the 'guerrillero arrepentido' (2011: 100) and on a teleological conception of history that sustains neoliberal hegemony. Since neoliberalism comes after the period of revolutionary upsurge, it appears as inevitable, as a new historical stage that transcends the previous stage. However, new shifts in contemporary Latin American politics, Beverley claims, cannot be articulated without reassessing the heritage of the armed struggle and without embracing a new historical paradigm: that of restoration. Following this paradigm, the 1960s and 1970s do not belong to an old and immature historical stage but to a process that was repressed or deferred and whose elements continue to be active and can reemerge and be set in motion once again. 
Although I find Beverley's claims thought-provoking (in particular, the idea that it is necessary to reassess the heritage of the armed struggle in order to account for new shifts in Latin American politics), I believe that his arguments do not quite fit within contemporary Argentina. As I explained in the previous sections, since the mid-1990s - and, especially, since the advent of the Kirchner administration in 2003-the representation of left-leaning violence has not rested on a paradigm of disillusion but on a privatized and highly-romanticized conception of activism. It has not been based on the figure of the 'guerrillero arrepentido' but on the image of the everyday heroic militant. It is precisely the members of the second generation, especially those who share a biographical connection with the disappeared activists, who are responsible for this centrality. In this sense, Benjamín Ávila’s film does not embody a marginal discourse but one that has become hegemonic and that in fact dominates national memory. The director himself celebrates the Argentine Public Television's sponsorship, recognizes his sympathy for the official administration, and acknowledges his ties with H.I.J.O.S. (Ranzani, 2012). As Quintín notes, the movie is a typical product of the 'cine kirchnerista' (2012). Far from being the dominant trend in the representation of the armed struggle, the paradigm of disillusion is a view that, as Infancia clandestina suggests, has become peripheral in contemporary Argentina. ${ }^{13}$

Furthermore, Beverley's observations regarding the links between the representation of the armed struggle and a teleological conception of history are also worth reexamining for the

\footnotetext{
${ }^{13}$ Beverley himself indirectly suggests that this is the case when stating that 'there is a relation between how one thinks about the armed struggle in Latin America and how one thinks about the nature and possibilities of the new governments of the marea rosada' (2011: 95). Following his argument, if the paradigm of disillusion dominated contemporary Argentina, the Kirchner administration would not have such a strong support. Maybe the problem with Beverley's assessment is that he is basing his claims on Beatriz Sarlo, who is actually a marginal voice in this respect.
} 
Argentine case. Although the repentant discourse that underlies the paradigm of disillusion might be grounded in such a conception, the opposite representation (the one that is most popular today) is less grounded in restoration than in archaization. Ávila's film is emblematic in this respect: in contemporary hegemonic discourse, militancy is perceived as an archaic and auratic practice; as a private virtue untouched by the passing of time; as an object for cult and contemplation; as an iconic sign. Those elements that were repressed or deferred and that could be set in motion again remain latent, far below the surface of public memory. The biographical connection with activism, instead of inviting a political reexamination, is at the core of the subjective turn that sees militancy as an everyday family routine. The child's perspective allows for a coming-of-age narrative that-rather than bringing the political dimension of left-leaning violence to the fore-privatizes, romanticizes, and converts revolutionary violence into an individual trait. In sum, in contemporary Argentina the iconic representation of the armed struggle (and not the paradigm of disillusion) precludes the reassessment that could account for new shifts in Latin American politics and maybe break with neoliberal hegemony.

Important is to note that this particular representation does not only dominate contemporary Argentina but the international world. This version of militancy successfully circulates within global cinema. Infancia clandestina is only one example in a series of films that, via a child's or an adolescent's gaze, build a privatized and romanticized version of recent Argentine history and are (thus) worldwide acclaimed. Gastón Biraben's Cautiva, Paula Markovitch’s El premio, Pablo Agüero’s Salamandra, Marcelo Piñeyro’s Kamchatka, or Daniel Bustamante's Andrés no quiere dormir la siesta (to name only a few paradigmatic post-2000 
films) are other fictions that follow this path. ${ }^{14}$ We could in fact argue that these movies' success point to a necessary link between iconicity and globalization. In the midst of late capitalism-in an age that, as Fredric Jameson famously stated, 'has forgotten how to think historically' (ix) - it is the iconic sign that best embodies the global cultural logic. Within the contemporary division of labor resulting from transnational business (with the transnational film industry being the paradigmatic example in the cultural field), Latin America's role seems to be relegated to providing iconic fictions that, like all icons, rely on instantaneous response but preclude further examination.

\section{Works Cited}

Andrés no quiere dormir la siesta. 2009. Directed by D. Bustamante. Buenos Aires: El Ansia Producciones.

Anguita, E. \& Caparrós, M. 1997. La voluntad: una historia de la militancia revolucionaria en la Argentina. Barcelona: Norma.

Aon, L. 2011. Una cuestión de representación: las películas de los directores-hijos. Estudios, 25: 219-230.

Ávila, B. 2012. Entrevista con Benjamín Ávila. Revista Cabal [online] 1 Oct, n.p. [Accessed 23 March 2013]. Available at: $\langle$ http://www.revistacabal.coop/entrevista-benjamin-avila-director-de\%E2\%80\%9Cinfancia-clandestina $>$

Balász, B. 1999. The Close-up. In: L. Braudy and M. Cohen, eds. Film Theory and Criticism: Introductory Readings. Oxford: Oxford University Press, pp. 304-305.

Benjamin, W. 1999. The Work of Art in the Age of Mechanical Reproduction. In: L. Braudy and M. Cohen, eds. Film Theory and Criticism: Introductory Readings. Oxford: Oxford University Press, pp. 731-751.

\footnotetext{
${ }^{14}$ See Garibotto , 2012 for a more comprehensive list of second-generation fictional films that are narrated through a child's or a teenager's perspective and for an examination of the differences with second-generation documentary production.
} 
Beverley, J. 2011. Latinamericanism after 9/11. Durham: Duke University Press.

Calveiro, P. 2005. Política y/o violencia: una aproximación a la guerrilla de los años 70. Buenos Aires: Norma.

Cautiva. 2005. Directed by G. Biraben [DVD]. Buenos Aires: Cacerolazo Producciones.

Cazadores de utopías. 1996. Directed by D. Blaustein [DVD]. Buenos Aires: SBP.

Crenzel, E. ed. 2010. Los desaparecidos en la Argentina. Memorias, representaciones e ideas (1983-2008). Buenos Aires: Biblos.

Deleuze, G. 1986. Cinema I, trans. by H. Tomlinson and B. Habberjam. Minneapolis: University of Minnesota Press.

of Minnesota Press.

1989. Cinema II, trans. by H. Tomlinson and B. Habberjam. Minneapolis: University

Doane, M. A. 2007. The Indexical and the Concept of Medium Specificity. differences: $a$

Journal of Feminist Cultural Studies, 18(1): 128-152.

Donatello, L.M. 2010. Catolicismo y montoneros. Religión, política y desencanto. Buenos Aires: Manantial.

Encontrando a Víctor. 2005. Directed by N. Bruschtein [DVD]. Mexico, Buenos Aires: Centro de Capacitación Cinematográfica.

Feierstein, L. 2012. Por una e(sté)tica de la recepción. La escucha social frente a los hijos de detenidos-desaparecidos en Argentina. Helix, 5:124-144.

Feinmann, J.P. 2012. El año que vivimos en peligro. Página 12 [online] 16 Sept, n.p. [Accessed 23 March 2013]. Available at: 〈http://www.pagina12.com.ar/diario/suplementos/radar/9-82312012-09-16.html>

Franco, M. 2012. Un enemigo para la nación: orden interno, violencia y "subversión" (19731976). Buenos Aires: Fondo de Cultura Económica.

Gamerro, C. 2011. Un yuppie en la columna del Che Guevara. Buenos Aires: Edhasa.

Garibotto, V. 2012. Iconic Fictions: Narrating Recent Argentine History in Post-2000 SecondGeneration Films. Studies in Hispanic Cinemas 8 (2):175-187.

.2010. Temporalidad e historia: hacia una reformulación del marco interpretativo del testimonio posdictatorial. Chasqui: revista de literatura latinoamericana, 39(2): 99-114.

Gelman, J. 1987. Conversaciones con Juan Gelman: contraderrota, montoneros y la revolución perdida. Buenos Aires: Contrapunto.

Gillespie, R. 1998. Los montoneros: soldados de Perón. Buenos Aires: Grijalbo. 
Gilman, C. 2003. Entre la pluma y el fusil: debates y dilemas del escritor revolucionario en América Latina. Buenos Aires: Siglo XXI.

Giussiani, P. 2011. Montoneros: la soberbia armada. Buenos Aires: Sudamericana.

H.I.J.O.S. 1995. Quiénes somos. HIJOS [online] n.d., n.p. [Accessed 2 May 2013]. Available at: <http://www.hijoscapital.org.ar/index.php?option=com_content $\& v i e w=$ article $\& i d=19 \& I t e m i d=400>$

Hirsch, M. 2001. Surviving Images: Holocaust Photographs and the Work of Postmemory. The Yale Journal of Criticism, 14 (1): 5-37.

La historia oficial. 1985. Directed by L. Puenzo [DVD]. Buenos Aires: Historias cinematográficas.

Infancia clandestina. 2012. Directed by B. Ávila [DVD]. Buenos Aires: Wandavisión.

Jameson, F. 1991. Postmodernism, or the Cultural Logic of Late Capitalism. Durham: Duke University Press.

Kairuz, M. 2012. Esto es lo que creo. Página 12 [online] 16 Sept, n.p. [Accessed 23 March 2013]. Available at: <http://www.pagina12.com.ar/diario/suplementos/radar/subnotas/82311802-2012-09-16.html>

Kamchatka. 2002. Directed by M. Piñeyro [DVD]. Buenos Aires: Patagonik.

Kirchner, N. 2004. Discurso por la creación del Museo de la Memoria. Wikisource [online] 24 March, n.p. [Accessed 18 March 2013]. Available at:

<http://es.wikisource.org/wiki/Discurso_de_N\%C3\%A9stor_Kirchner_por_la_creaci\%C3\%B3n del_Museo_de la_Memoria $>$

M. 2007. Directed by N. Prividera [DVD]. Buenos Aires: Trivial.

Moyano, M.J. 1995. Argentina's Lost Patrol: Armed Struggle (1969-1979). New Haven: Yale University Press.

Papá Iván. 2004. Directed by M.I. Roqué. [DVD]. Mexico: Zafra.

Peirce, C. 1982. Writings of Charles Peirce: a Chronological Edition, ed. by Max Fisch. Bloomington: Indiana University Press.

Pérez, M.E. 2012. Diario de una princesa montonera. Buenos Aires: Capital Intelectual.

Pérez Zabala, V. 2012. La doble vida de Juan. La nación [online] 15 Sept, n.p. [Accessed 21 January 2013]. Available at: 〈http://www.lanacion.com.ar/1508554-la-doble-vida-de-juan>

Podalsky, L. 2011. The Politics of Affect and Emotion in Contemporary Latin American Cinema: Argentina, Brazil, Cuba, and Mexico. New York: Palgrave Macmillan. 
El premio. 2011. Directed by P. Markovitch. Mexico, Paris, Berlin: Elite Studios, Foprocine, IZ Films.

Prince, S. 1999. The Discourse of Pictures: Iconicity and Film Studies. In: L. Braudy and M. Cohen, eds. Film Theory and Criticism: Introductory Readings. Oxford: Oxford University Press, pp. 99-117.

Quintín. 2012. Llega el cine kirchnerista. La lectora provisoria [online] 30 Sept, n.p. [Accessed 21 January 2013]. Available at: <http://lalectoraprovisoria.wordpress.com/2012/09/30/llega-elcine-kirchnerista>

Ranzani, O. 2012. Militancia no es sinónimo de muerte, sino de crecer. Página 12 [online] 20 May, n.p. [Accessed 21 January 2013]. Available at:

<http://www.pagina12.com.ar/diario/suplementos/espectaculos/2-25270-2012-05-20.html>

Rosen, P. 2001. Change Mummified: Cinema, Historicity, Theory. Minneapolis: University of Minnesota Press.

Los rubios. 2003. Directed by A. Carri [DVD]. Buenos Aires: Women Make Films.

El secreto de sus ojos. 2009. Directed by J.J. Campanella [DVD]. Buenos Aires: Tornasol Films.

Salamandra: niños de la Patagonia. 2008. Directed by P. Agüero [DVD]. Buenos Aires, Paris, Berlin: JBA Production, Rohfilm.

Scholz, P. 2012. Infancia clandestina: la Argentina elegida para el Oscar. Clarín [online] 28 Sept, n.p. [Accessed 19 February 2013]. Available at:

<http://www.clarin.com/espectaculos/cine/Infancia-clandestina-argentina-elegidaOscar_0_782921793.html>

Silverman, K. 1983. The Subject of Semiotics. Oxford: Oxford University Press.

Vezzetti, H. 2002. Pasado y presente: guerra, dictadura y sociedad en la Argentina. Buenos Aires: Siglo XXI.

XXI. .2009. Sobre la violencia revolucionaria: memorias y olvidos. Buenos Aires: Siglo

Mi vida después. 2009. Directed by L. Arias [Theatre]. Buenos Aires.

Wollen, P. 1972. Sign and Meaning in the Cinema. Bloomington: Indiana University Press.

Young, N. 2012. Clandestine Childhood: Cannes Review. The Hollywood Reporter [online] 21 May, n.p. [Accessed 19 May 2013]. Available at: <http://www.hollywoodreporter.com/review/clandestine-childhood-cannes-review-327182>

Zuker, C. 2003. El tren de la victoria. Buenos Aires: Sudamericana. 